\title{
PRE- and POST-STORM LIDAR SURVEYS FOR ASSESSMENT OF IMPACT ON COASTAL EROSION
}

\author{
A-L. Montreuil ${ }^{1}$, M. Chen ${ }^{1}$, A. Esquerré ${ }^{1}$, R. Houthuys ${ }^{2}$, R. Moelans ${ }^{2}$, P. Bogaert ${ }^{3}$ \\ ${ }^{1}$ Hydrology and Hydraulic Engineering, Vrije Universiteit Brussel, Belgium - anne-lise.montreuil@ vub.be, margaret.chen@vub.ac.be, \\ alexis.philippe.henri.esquerre@vub.be \\ ${ }^{2}$ VITO, Mol, Belgium - rik.houthuys@ telenet.be, robrecht.moelans@ vito.be, \\ ${ }^{3}$ Pole of Environmental Sciences, Université catholique de Louvain, Belgium - patrick.bogaert@uclouvain.be
}

\section{Commission VI, WG VI/4}

KEY WORDS: Topographic monitoring, Coastline, Beach features, Morphology, Belgian coast

\begin{abstract}
:
Sustainable management of the coastal resources requires a better understanding of the processes that drive coastline change. The coastline is a highly dynamic sea-terrestrial interface. It is affected by forcing factors such as water levels, waves, winds, and the highest and most severe changes occur during storm surges. Extreme storms are drivers responsible for rapid and sometimes dramatic changes of the coastline. The consequences of the impacts from these events entail a broad range of social, economic and natural resource considerations from threats to humans, infrastructure and habitats. This study investigates the impact of a severe storm on coastline response on a sandy multi-barred beach at the Belgian coast. Airborne LiDAR surveys acquired pre- and post-storm covering an area larger than $1 \mathrm{~km}^{2}$ were analyzed and reproducible monitoring solutions adapted to assess beach morphological changes were applied. Results indicated that the coast retreated by a maximum of $14.7 \mathrm{~m}$ where the embryo dunes in front of the fixed dunes were vanished and the foredune undercut. Storm surge and wave attacks were probably the most energetic there. However, the response of the coastline proxies associated with the mean high water line (MHW) and dunetoe (DuneT) was spatially variable. Based on the extracted beach features, good correlations ( $r>0.73$ ) were found between coastline, berm and inner intertidal bar morphology, while it was weak with the most seaward bars covered in the surveys. This highlights the role of the upper features on the beach to protect the coastline from storm erosion by reducing wave energy. The findings are of critical importance in improving our knowledge and forecasting of coastline response to storms, and also in its translation into management practices.
\end{abstract}

\section{INTRODUCTION}

The coastline is a highly dynamic sea-terrestrial interface. Approximately $31 \%$ of the world's coastline is sandy of which $24 \%$ is subject to erosion (Luijendijk et al., 2018). Sandy beaches are important for the economic and recreational activity as well as for coastal protection because they form a natural buffer against erosion and flooding for lowlands. In the context of climate change, the elevation of water levels combined with changing of wave conditions through sea-level rise and storminess, dramatically menace sandy coasts and inland infrastructure (Feagin et al., 2005). Beach response to storms is highly variable due to the nature of the storm forcing factors (water levels, waves, winds), the characteristics of the coast such as the presence of morphological features (e.g. berm, bar bedforms) and geologic setting (Cooper et al., 2004).

Understanding coastline impact requires collecting datasets for monitoring its natural change in suitable temporal and spatial resolution which is challenging, especially in relation to a storm occurrence. Nowadays, airborne LiDAR (Light Detecting and Ranging), an active remote sensing system, represents one of the most effective technologies and is increasingly used in beach topographic monitoring (Middleton et al., 2013). Previous studies have demonstrated its ability to collect high resolution, instantaneous, dense and accurate topographic data over large sections of coastlines (e.g. Sallenger et al., 2003, Deronde et al., 2008, Le Mauff et al., 2018). Also, the acquisition of consecutive LiDAR surveys allows to monitor successfully the changes of the coastline as well as the 3D morphological variation of the beach system (Saye et al., 2005, Pye and Blott, 2016).

Mapping the coastline position and migration over time is one of the traditional and common methods to determine beach changes. A number of established metrics are traditionally applied to extract the coastline from LiDAR data. One category is to measure a static proxy as a datum-based contour line, which is defined as the intersection of the beach morphology with a specific elevation plane. Commonly, the mean high water level (MHW), determined from the local tide gauge, has been applied in previous studies (e.g. Ruggiero et al., 2003, Saye et al., 2005, Farris and List, 2007). Another category involves the use of a dynamic proxy like the dunetoe (DuneT) varying with the height and shape changes between and within different beach systems. It is thus related to the morphological state (Le Mauff et al., 2018). The development of a reproducible and comparable approach to extract geomorphic indicator has become a key methodology challenge.

The aim of this study is to characterize the coastline response of a severe storm along a sandy multi-barred beach. The originality of this work is to use a detailed morphological dataset of a preand an immediate post-storm LiDAR surveys. This exceptional database offers the possibility to extract and compare different coastline proxies and to investigate their relationships with the intertidal bars ubiquitous on such a beach. 


\section{STUDY SITE}

The Belgian coast extends for $67 \mathrm{~km}$ from the French Opal coast to the border with the Netherlands (Figure 1) and is oriented SWNE. In general, the coast consists of broad dissipative sandy beaches which at low tide are up to $600 \mathrm{~m}$ wide and numerous sand banks in the shallow continental zone.

The study site is located at Groenendijk, a natural sandy beach of $500 \mathrm{~m}$ wide with an overall slope of less than $1 \%$ (Figure 1). Well-developed foredunes of approximately $10 \mathrm{~m}$ high above TAW (Belgium Ordnance Datum corresponding to the low spring tide in Oostende) are present and relatively well covered by marram grasses. The beach is also characterized by a system of multiple bars-troughs in the intertidal zone, between the mean high water level and low water line and breaker bars continue to be present on the upper shoreface (Figure 2). The sediment on the beach consists of medium fine sand with a D50 of $200 \mu \mathrm{m}$.

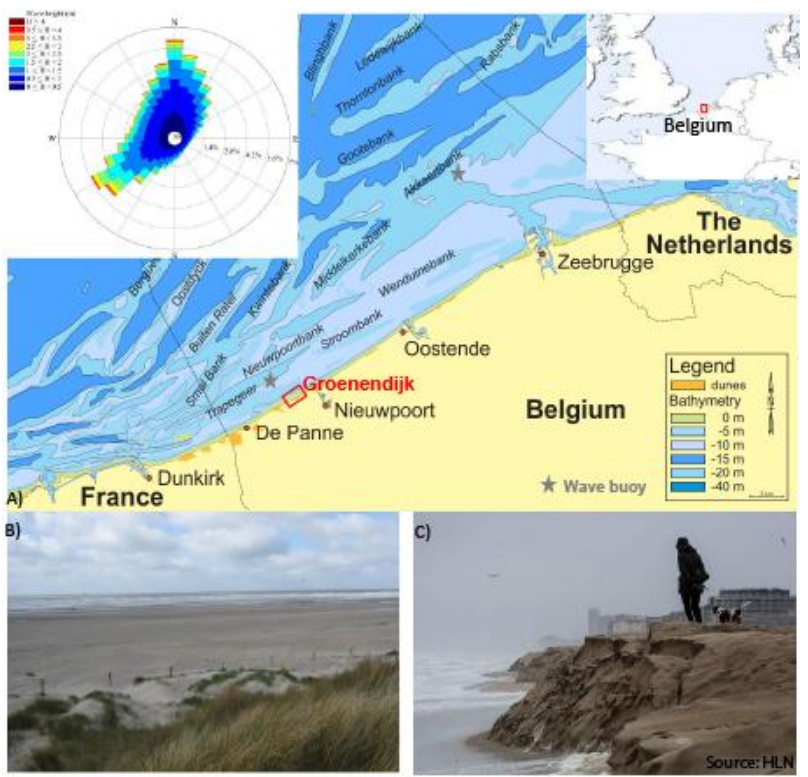

Figure 1. Map of the study site; inset: annual wave rose. Ground photographs B) before, and C) immediately after the storm.

The beach is situated in a macro-tidal environment with a range between $3.5 \mathrm{~m}$ at neap tide and $5 \mathrm{~m}$ at spring tide. The wave regime is characterized by an onshore wave height below $1 \mathrm{~m}$ (Figure 1) and a wave period of 3.5-4.5 s. The dominant wave sectors are from SW to NW, which are mainly driven by westerly winds resulting in a longshore drift towards the northeast. During $\mathrm{N}$ and NW energetic hydrodynamic conditions, severe storm surges with onshore wave heights of $3 \mathrm{~m}$ can push water level above 5 m TAW (Haerens et al., 2012).

\section{METHODOLOGY}

\subsection{LiDAR measurements}

LiDAR measures the attitude, direction and propagation time of laser pulses from an airborne platform to the ground and back, using an integrated multi-sensor system which consists of a laser. Real-time kinematic Global Positioning System, and an Inertial Measurement Unit. A rotating mirror deployed in front of the laser causes it to scan back and forth, allowing to cover a wide swath beneath the flight path.
LiDAR surveys using a Riegl Q680i system were commissioned by Coastal Division along the Belgian coast before (14/12/2016) and immediately (17/01/2017) after the "Dieter" storm. The data were filtered to remove vegetation and buildings and were made available in txt file format consisting of $\mathrm{x}, \mathrm{y}, \mathrm{z}$ values. After filtering, the point density ranged from 1 to 5 points per $\mathrm{m}^{2}$. The root mean square error determined on ground control points of the pre-storm and post-storm survey was $2.5 \mathrm{~cm}$ and $3.1 \mathrm{~cm}$ respectively. The coverage of the LiDAR data is limited to the area above the instantaneous low water mark due to the high turbidity of the coastal waters and the type of system used.

LiDAR surveys generate a cloud of points with irregular spacing caused by the zigzag scanning pattern. It is thus difficult to directly compare changes in beach topography from two different surveys because the horizontal coordinates of the cloud of points are not directly matched. Hence, point data per survey were used to generate a Triangulated Irregular Network (TIN) and then converted it to a digital elevation model (DEM) of $1 \mathrm{~m}$ cell size for topographic comparison. Also, models of roughness were produced by determining the standard deviation of the point clouds per cell of $1 \mathrm{~m}$. The boundaries of the models are about $50 \mathrm{~m}$ from the foredune crest to an elevation of $0 \mathrm{~m}$ TAW; and an area larger than $1 \mathrm{~km}^{2}$ is covered.
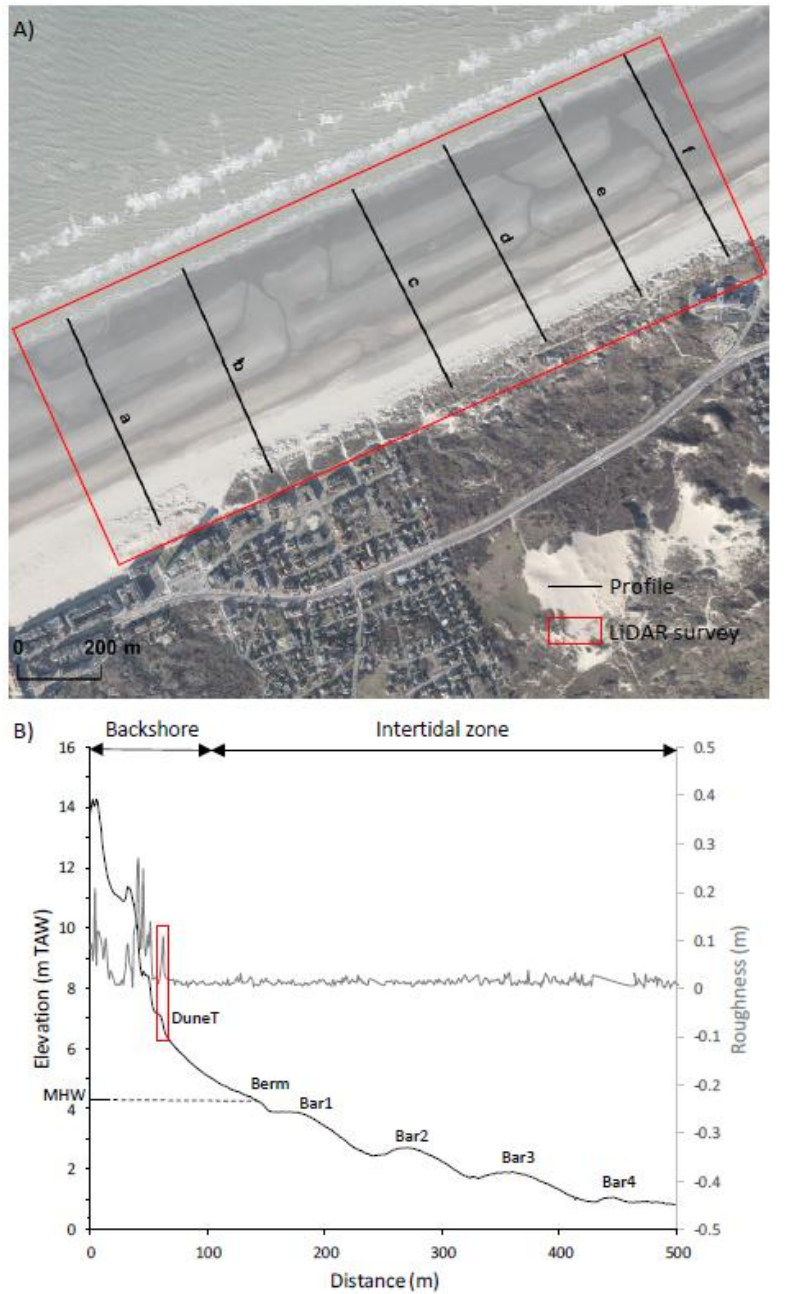

Figure 2. A) Area of the LiDAR surveys and beach profiles location, B) Coastline detections of the MHW and DuneT indicators. DuneT is extracted using the roughness method. 


\subsection{Extraction of coastline and marine features}

In this study, the coastline was identified using both the MHW datum-based line and the dynamic indicator of DuneT and then compared between the surveys. The MHW isocontour was simply extracted from the DEMs corresponding to the elevation of $4.39 \mathrm{~m}$ TAW, a value used since several decades as a proxy, while the DuneT was detected as a sudden increase of roughness across the beach. Also, the intertidal beach characterized by the presence of one backshore berm and three intertidal bars was delineated from the TINs using visual ruptures in the beach topography. Furthermore, 6 profiles (a-f) were generated perpendicular to the coast with spacings from $250 \mathrm{~m}$ to $475 \mathrm{~m}$ (Figure 2) to extract various morphometric parameters from the coastline and the intertidal features per survey in order to investigate the mutual correlations between them and the change across the storm (Table 1).

\begin{tabular}{|c|c|}
\hline $\begin{array}{l}\text { Morphometric } \\
\text { parameter }\end{array}$ & Definition \\
\hline $\begin{array}{l}\text { Coastline distance } \\
(\mathrm{m})\end{array}$ & $\begin{array}{l}\text { Distance from the fixed landward } \\
\text { elevation measurement to the dunetoe }\end{array}$ \\
\hline $\begin{array}{c}\text { Coastline } \\
\text { elevation }(\mathrm{m})\end{array}$ & Height of the dunetoe above TAW \\
\hline Coastline slope $\left(^{\circ}\right)$ & $\begin{array}{l}\text { Height difference between the dunetoe } \\
\text { and crest divided by the distance } \\
\text { between them }\end{array}$ \\
\hline Dune volume $\left(\mathrm{m}^{3}\right)$ & $\begin{array}{l}\text { Sand volume from the fixed landward } \\
\text { elevation measurement to the dunetoe }\end{array}$ \\
\hline $\begin{array}{c}\text { Intertidal zone } \\
\text { volume }\left(\mathrm{m}^{3}\right)\end{array}$ & $\begin{array}{l}\text { Sand volume from the dunetoe to the } \\
\text { MLW of } 1.39 \text { m TAW }\end{array}$ \\
\hline $\begin{array}{c}\text { Bar/Berm width } \\
(\mathrm{m})\end{array}$ & $\begin{array}{l}\text { Distance between seaward and landward } \\
\text { boundaries of the bar or berm }\end{array}$ \\
\hline $\begin{array}{l}\text { Bar/Berm seaward } \\
\text { distance }(\mathrm{m})\end{array}$ & $\begin{array}{l}\text { Position of the seaward boundary of the } \\
\text { bar or berm }\end{array}$ \\
\hline $\begin{array}{c}\text { Bar/Berm } \\
\text { land distance }(\mathrm{m})\end{array}$ & $\begin{array}{l}\text { Position of the landward boundary of the } \\
\text { bar or berm }\end{array}$ \\
\hline $\begin{array}{l}\text { Bar/Berm seaward } \\
\text { elevation }(\mathrm{m})\end{array}$ & $\begin{array}{l}\text { Elevation of the seaward boundary of } \\
\text { the bar or berm }\end{array}$ \\
\hline $\begin{array}{l}\text { Bar/Berm landard } \\
\text { elevation }(\mathrm{m})\end{array}$ & $\begin{array}{l}\text { Elevation of the landward boundary of } \\
\text { the bar or berm }\end{array}$ \\
\hline
\end{tabular}

Table 1. Definitions of the morphometric parameters.

\subsection{Hydrodynamic measurements}

Water level and wave parameters were examined to determine the conditions of the forcing factors during the study period from $14 / 12 / 2016$ to $17 / 01 / 2017$. Five-minute measurements of the water level were obtained from the nearest tide gauge at Nieuwpoort at $2 \mathrm{~km}$ distance from the study site. Bi-hourly wave heights were recorded from Trapegeer wave buoy, located at 6 $\mathrm{km}$ from the study site, and wave direction and energy records were from Akkaert Zuid, an offshore wave buoy (Figure 1). All these data were supplied by Meetnet Vlaamse Banken (https://meetnetvlaamsebanken.be/).

\section{RESULT AND DISCUSSION}

\subsection{Storm activity}

In the North Sea basin, the severe Dieter storm from NNW occurred on $14^{\text {th }}-15^{\text {th }}$ January 2017 in relation to a depression located above the North of Europe. Figure 3 presents the marine conditions nearby the study site from $14^{\text {th }}$ December 2016 to $17^{\text {th }}$
January 2017, corresponding to the period between the two LiDAR surveys.

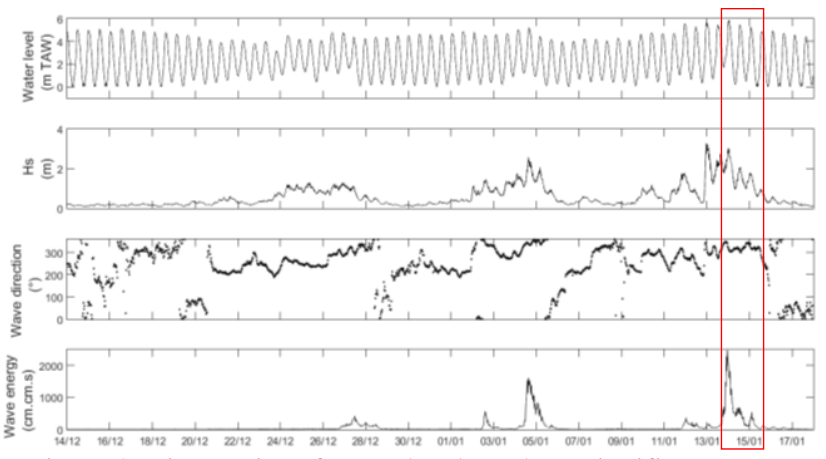

Figure 3. Time series of water level, onshore significant wave height (Hs), wave direction and wave energy between the LiDAR surveys. The red box corresponds to the Dieter storm event.

The most energetic period of the storm took place between 12am on $14^{\text {th }}$ January and 2 am on $15^{\text {th }}$ January during which the maximum water level reached $5.89 \mathrm{~m}$ TAW on $14^{\text {th }}$ January at midnight with a peak significant wave height (Hs, the highest $33 \%$ of the waves) of $2.87 \mathrm{~m}$ and wave energy of $2150 \mathrm{~cm} . \mathrm{cm} . \mathrm{s}$. Waves came from NW-NNW $\left(300^{\circ}-330^{\circ}\right)$, which is the most destructive sector for the Belgian coast during storms (Montreuil et al., 2017). The storm threshold for significant morphological change, defined as a water level above $5 \mathrm{~m}$ TAW by Haerens et al. (2012), was exceeded by $0.89 \mathrm{~m}$ during the event. After the storm, the water level decreased, though wave heights remained large for about 3 hours. Then they rapidly dropped to reach typical values below $1 \mathrm{~m}$ (not presented in Figure 3).

\subsection{Storm impact on the coastlines}

Data clearly show an overall erosion after the storm event with an average landward retreat of the DuneT of $-6.92 \mathrm{~m}$ and a maximum land retreat of $-14.70 \mathrm{~m}$ (Figure 4 and Table 2). This trend also occurred for the MHW contour under a lower magnitude with an average of $-3.13 \mathrm{~m}$. The difference of DEMs between the pre- and post-storm DEMs shows that the foredune was undercut and the seaward embryo dunes located between the centre and the eastward limit of the study site were vanished after the storm. Also, a considerable alongshore variability of the elevation change of the DuneT was observed, ranging from 0.2 to $0.73 \mathrm{~m}$. A thin, elongated and almost continuous strip of erosion with elevation differences up to -0.18 m occurred seaward of the MHW line and continued toward the east, except nearby the profile a. In addition, the sinuosity of the DuneT per survey was also calculated. It corresponds to the total length of the line divided by the shortest distance between the extremities.

The sinuosity index of the DuneT, characterized by vegetated foredunes and patches of embryo dunes before the pre-storm survey was 0.65 , while it was 0.86 for the post-storm survey. This indicates that the coastline was straighter after the storm event due to the wave undercutting and removing of sand from the dune leading to a dune cliff (Figure 1C).

Both the DuneT and MHW proxies varied alongshore with a large displacement landward from the centre to the eastward side of the study site (from profile $\mathrm{c}$ to $\mathrm{f}$ ). However, they evolved in opposing ways for profile a. The DuneT moved landward (erosion) while the MHW moved seaward (accretion) probably 
due to the welding of the berm to the backshore. Spatial and temporal variability of the coastline change is mainly controlled by the total water level associated with tide, wave height, and wave run-up, which is in turn governed by the antecedent beach morphology (Cooper et al., 2004). Due to this, the MHW is overly sensitive to fluctuations of the water level, and the continuous process-response between the intertidal zone and the backshore. Therefore, the MHW contour based-datum does not reflect the upper beach morphology in terms of its overall profile shape and response. It should not be used to conduct coastline change analysis for dissipative multi-barred beaches. An appropriate coastline proxy should identify the location of the land reflecting the natural response in beach morphology and forcing factors, and hence capturing the distinctive morphological characteristics of the storm impact (Morton and Speed, 1998)
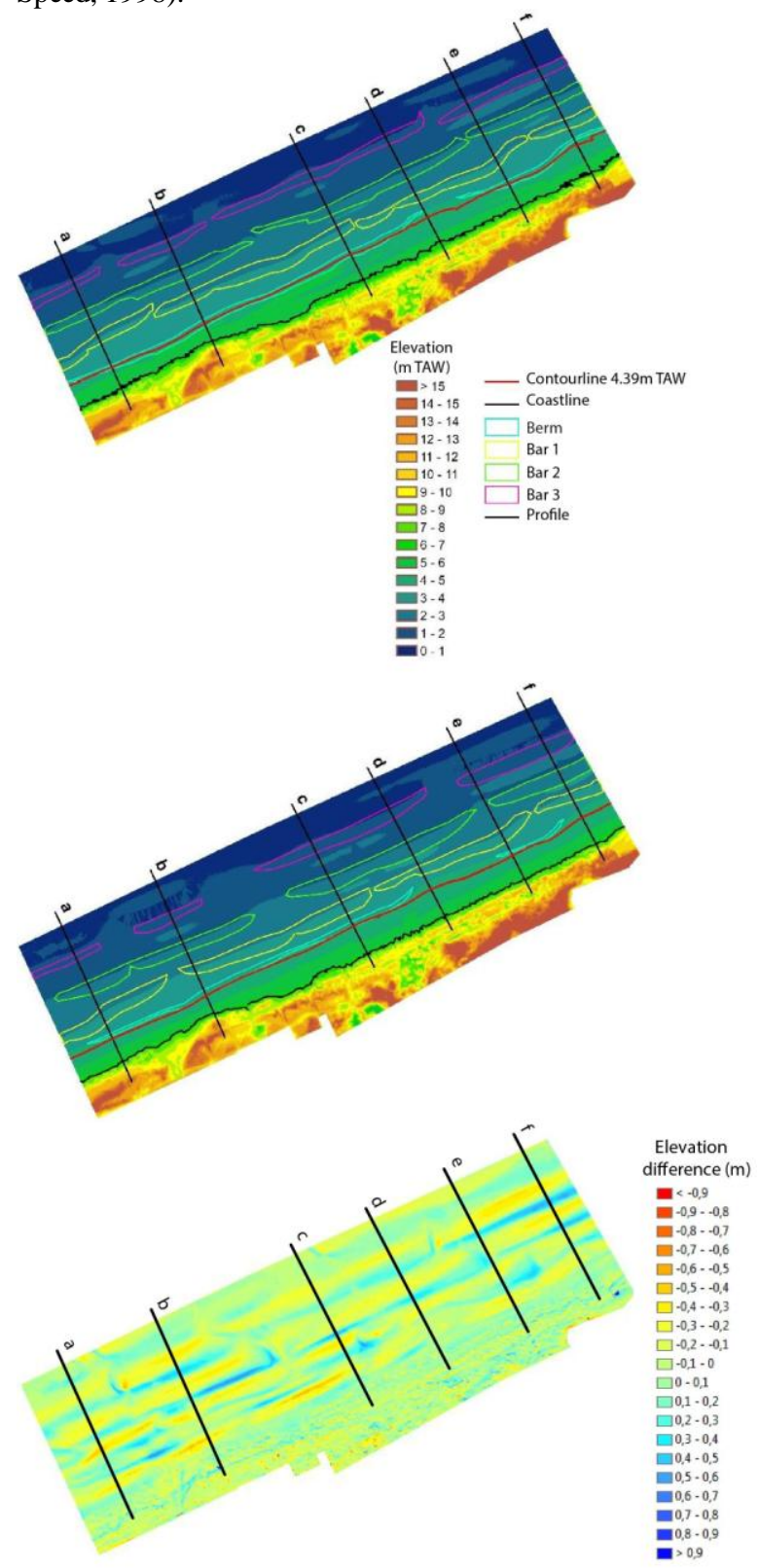

Figure 4. Extracted coastline indicators and beach morphological features superimposed on the DEMs of the pre- (14/12/2016) and post-storm (17/01/2017), and difference of DEMs

\begin{tabular}{|c|c|c|c|}
\hline & \multicolumn{4}{|c|}{ Difference between pre- and post-storm survey } \\
\hline Profiles & $\begin{array}{c}\text { MHW } \\
\text { position } \\
(\mathbf{m})\end{array}$ & $\begin{array}{c}\text { DuneT } \\
\text { position } \\
(\mathbf{m})\end{array}$ & $\begin{array}{c}\text { DuneT } \\
\text { elevation } \\
(\mathbf{m})\end{array}$ \\
\hline a & 0.99 & -4.00 & 0.49 \\
\hline b & -2.00 & -1.70 & 0.20 \\
\hline c & -3.96 & -11.20 & 0.64 \\
\hline d & -4.13 & -14.70 & 0.73 \\
\hline e & -3.00 & -5.30 & 0.51 \\
\hline f & -6.70 & -4.60 & 0.44 \\
\hline Mean & -3.13 & -6.92 & 0.50 \\
\hline
\end{tabular}

Table 2. Difference between the coastline detection of the MHW and DuneT proxies as a function of the profiles.

\subsection{Relationships between the coastline and beach morphological features}

A set of coastline and beach characteristics was extracted to investigate the mutual correlations between morphometric parameters of the coastline distinct as the DuneT with the berm and bar characteristics. Table 3 summarises the strong Pearson's correlation coefficients evaluated from the six profiles for the two surveys. The highest correlation $(\mathrm{r}=0.95)$ is found between the coastline distance and the dune volume. It indicates that a retreat of the DuneT is related to a decrease of dune volume. Moreover, the volume of the intertidal beach is also correlated to the coastline with a coefficient of -0.94 , revealing that the volume of the intertidal zone is negatively related to the elevation of the DuneT. This suggests that when the volume of the intertidal zone increases, the DuneT falls down. Overall, these strong correlations show that the coastline parameter DuneT is a good proxy for volume change.

\begin{tabular}{|c|c|}
\hline Coastline distance & Coastline elevation \\
\hline Dune volume: 0.95 & Coastline slope: 0.72 \\
Pre-storm: $228.61 \mathrm{~m}^{3} / \mathrm{m}$ & Pre-storm: $3.70^{\circ}$ \\
Post-storm: $202.59 \mathrm{~m}^{3} / \mathrm{m}$ & Post-storm: $5.45^{\circ}$ \\
\hline Berm width: 0.73 & Intertidal zone volume: -0.94 \\
Pre-storm: $16.18 \mathrm{~m}$ & Pre-storm: $443.98 \mathrm{~m}^{3} / \mathrm{m}$ \\
Post-storm: $11.53 \mathrm{~m}$ & Post-storm: $413.12 \mathrm{~m}^{3} / \mathrm{m}$ \\
\hline Bar 1 land distance: 0.80 & Berm land elevation: -0.81 \\
Pre-storm: $198.50 \mathrm{~m}$ & Pre-storm: $132.00 \mathrm{~m}$ \\
Post-storm: $183.83 \mathrm{~m}$ & Post-storm: $134.12 \mathrm{~m}$ \\
\hline Bar 1 sea distance: 0.83 & Berm sea elevation: -0.60 \\
Pre-storm: $229.85 \mathrm{~m}$ & Pre-storm: $132.00 \mathrm{~m}$ \\
Post-storm: $219.67 \mathrm{~m}$ & Post-storm: $134.12 \mathrm{~m}$ \\
\hline Bar 2 land distance: 0.61 & Berm width: -0.76 \\
Pre-storm: $278.85 \mathrm{~m}$ & Pre-storm: $16.18 \mathrm{~m}$ \\
Post-storm: $258.00 \mathrm{~m}$ & Post-storm: $11.53 \mathrm{~m}$ \\
\hline Bar 3 width: -0.61 & Bar2 width: -0.65 \\
Pre-storm: $26.54 \mathrm{~m}$ & Pre-storm: $32.57 \mathrm{~m}$ \\
Post-storm: $32.53 \mathrm{~m}$ & Post-storm: $43.33 \mathrm{~m}$ \\
\hline Table 3. Summ &
\end{tabular}

Table 3. Summary of high correlation coefficients $(\geq 0.6)$ between the coastline distinct as DuneT and beach morphological features $(\mathrm{p}<0.05)$ associated with mean characteristics of the morphometric parameters.

Those findings are in agreement with Farris and List (2007) who reported that the coastline change is a useful proxy for subaerial volume change. They stated that the beach volume can be derived from the coastline change as $\mathrm{d}_{\mathrm{v}}=\mathrm{H} \times \mathrm{d}_{\mathrm{s}}$, where $\mathrm{d}_{\mathrm{v}}$ is subaerial volume change, $\mathrm{H}$ is the height of the active profile above MHW, and $d_{S}$ is the change in coastline position. Here, the formula underestimates the sand loss up to $13 \mathrm{~m}^{3} / \mathrm{m}$. 
As expected, the correlation coefficient between coastline elevation and the slope is high $(\mathrm{r}=0.72)$, with an average slope of $3.7^{\circ}$ and $5.45^{\circ}$ for the pre-and post-storm respectively. In general good correlations ( $r>0.73$ ) were found between coastline, berm and the inner intertidal bar (bar 1) morphology, while they were weak with the most seaward bars covered in the surveys. This highlights the role of the upper features on the beach to have protected the coastline from storm erosion by reducing wave energy, while the lower features might have played a minor role during the Dieter storm.

\subsection{Coastal monitoring and management}

Along the Belgian coast, LiDAR surveys have been routinely carried out at least two times per year within a long-lasting and permanent program. Nevertheless, performing additional poststorm LiDAR surveys is strongly advised. This enables not only to map elevation changes along the coast, but also to identify the contribution of an isolated event in coastline response as well as to investigate in detail the spatial and temporal variability of beach morphological change. For future planning and decisionmaking, adaptive coastal management strategies must cope with the enhanced storminess and the progressively accelerating of sea level rise (Spencer et al., 2015). The development of predictive environmental modelling would allow us to understand and plan for the combination of these factors as multi-scenario outcomes. These can be investigated and fed into storm surge forecasting to assess coastal vulnerability in order to improve environmental security, through the implementation of early storm warning systems.

\section{CONCLUSIONS}

In this paper, the response of the sandy coastline of a multibarred beach to a severe storm was investigated and further used to diagnose the relationship with beach morphological features using pre- and immediate post-storm airborne LiDAR surveys. Results indicated that the coast retreated up to $14.7 \mathrm{~m}$ where the embryo dunes in front of the fixed dunes were vanished and the foredune undercut. This probably occurred when the maximum water level reached $5.89 \mathrm{~m}$ TAW with a significant wave height of $2.87 \mathrm{~m}$ and energy of $2150 \mathrm{~cm} . \mathrm{cm} . \mathrm{s}$.

The response of the coastline expressed by profile-based proxies associated with the static datum-base line of the MHW and the dynamic DuneT was spatially variable and even subject locally to divergent displacement trend. The difference of change between MHW and DuneT is related to both marine forcing factors and morphological characteristics of the beach. The correlation analysis showed that the highest coefficient values occurred between the coastline morphology and beach volumes. This indicates that a horizontal or vertical retreat of the coastline is related to a decrease of dune volume and an accretion of the intertidal beach. Based on the extracted beach features, good correlations $(r>0.73)$ were found between coastline, berm and inner intertidal bar morphology, while it was weak with the most seaward bars covered in the surveys. This highlights the role of the upper features on the beach to protect the coastline from storm erosion by reducing wave energy.

Beach topographic survey soon preceding and following storm occurrence is a challenge in terms of data collection and monitoring, but critical for improving our knowledge. Reliable assessments of the storm impact on coastline and beach morphological changes are basic necessities for a sustainable coastal management and an effective security planning, as well as for a mitigation of the enhanced storminess and sea level rise.

\section{ACKNOWLEDGEMENTS}

The authors thank the Belgian Science Policy Office for providing funding under STEREOIII project SR/00/360. We also thank the Coastal Division for providing the LiDAR data.

\section{REFERENCES}

Cooper, J.A.G, Jackson, D.W.T., Navas, F., McKenna, J.,Malvarez, G., 2004. Identifying storm impacts on an embayed, high energy coastline: examples from western Ireland.
Marine
Geology,
210 ,
261-280. doi:10.1016/j.margeo.2004.05.012

Deronde, B., Houthuys, R., Henriet, J-P., Van Lancker, V., 2008. Monitoring of the sediment dynamics along a sandy shoreline by means of airborne hyperspectral remote sensing and LIDAR: a case study in Belgium. Earth Surface Processes and Landforms, 33, 280-294. doi: 10.1002/esp.1545

Farris, A., S., List, J., H., 2007. Shoreline change as a proxy for subaerial beach volume change. Journal of Coastal Research, 23 (3), 740-748. doi:10.2112/05-0442.1

Feagin, R.A., Sherman, D.J., Grant,W.E., 2005. Coastal erosion, global sea-level rise, and the loss of sand dune plant habitats. Frontiers in Ecology and the Enironment. 3 (7), 359-364.

Haerens, P., Bolle, A., Trouw, K., Houthuys, R., 2012. Definition of storm thresholds 794 for significant morphological change of the sandy beaches along the Belgian coastline. Geomorphology, 143 , doi:10.1016/j.geomorph.2011.09.015.

Le Mauff, B., Juigner, M., Ba, A., Robin, M., Launeau, P., Fattal, P., 2018. Coastal monitoring solutions of the geomorphological response of beach-dune systems using multitemporal LiDAR datasets (Vendée coast, France).Geomorphology, $304, \quad 121$ 140.doi.org/10.1016/j.geomorph.2017.12.037

Luijendijk, A., Hagenaars, G., Ranasinghe, R., Baart, F., Donchyts, G., Aarninkhof, S., 2018. The State of the World's Beaches. Scientific Reports, 8, 6641.doi.org/10.1038/s41598018-24630-6.

Middleton, J.H., Cooke, C.G., Kearney, E.T., Mumford, P.J., Mole, M.A., Nippard, G.J., Rizos, C., Splinter, K.D., Turner, I.L., 2013. Resolution and accuracy of an airborne scanning laser system for beach surveys. Journal of Atmospheric and Oceanic Technology, 30, 2452-2464. doi: 10.1175/JTECH-D-1200174.1

Montreuil, A-L., Chen, M., Elyahyioui, J., 2017. Assessment of the impacts of storm events for developing an erosion Index. Regional Studies in Marine Science, 16, 124-130. doi.org/10.1016/j.rsma.2017.08.014 
Morton, R.A., Speed, F.M. 1998. Evaluation of shorelines and legal boundaries controlled by water levels on sandy beaches. Journal of Coastal Research. 14(4), 1373-1384.

Ruggiero, P., Kaminsky, G., M., Gelfenbaum, G. 2003. Linking proxy-based and datum-based shorelines on a high-energy coastline: implications for shoreline change analysis. Journal of Coastal Research, 38, 57-82.

Sallenger, A.H., Krabill, W.B., Swift, R.N., Arens, J., List, J.H., Hansen, M., Holman, R.A., Manizade, S., Sontag, J., Meredith, A., Morgan, K., Yunkel, J.K., Frederick, E.B., Stockdon, H., 2003. Evaluation of airborne topographic LIDAR for quantifying beach changes. Journal of Coastal research, 19(1), 125-133.

Saye, S.E., Van der Wal, D., Pye, K., Blott, S. J. 2005. Beachdune morphological relationships and erosion/accumulation: An investigation at five sites in England and Wales using Lidar data. Geomorphology, 72, 128-155. doi:10.1016/j.geomorph.2005.05.007.

Spencer, T., Brooks, S.M., Evans, B.R., Tempest, J., A., Möller, I. 2015. Southern North Sea storm surge event of 5 December 2013: water levels, waves and coastal impacts. Earth-Science Reviews, 146, 120-145.

Pye, K., Blott, S.J., 2016. Assessment of beach and dune erosion and accretion using LiDAR: impact of the stormy 2013-14 winter and longer term trends on the Sefton coast, UK. Geomorphology, 266, 146-167. doi.org/10.1016/j.geomorph.2016.05.011. 